\title{
Change in Distribution and Density of CGRP, PGP 9.5, Serotonin and Chromogranin A Immunoreactivity in the Perinatal Rat Respiratory Tract
}

\author{
Shuhei Inoue, Mineko Fujimiya*, Toshihiro Maeda* and Atsumi Mori \\ Second Department of Surgery and *Department of Anatomy, Shiga University of Medical Science, Seta, Otsu, Shiga, \\ $520-21$
}

Received for publication June 17, 1997 and in revised form September 3, 1997

Distribution and density of calcitonin generelated peptide (CGRP), protein gene product (PGP) 9.5, serotonin and chromogranin A immunoreactivity were examined in developing rat respiratory tracts from embryonic day (ED) 15 to postnatal day (PD) 60. On ED 15, the epithelium of the primitive bronchi stained positively for CGRP, PGP 9.5, serotonin and chromogranin A. CGRP, PGP 9.5, serotonin and chromogranin $A$ positive endocrine cells extended distally along the developing bronchial trees. Cell number reached a maximum on ED 19 or ED 17. On
ED 21, the clusters of endocrine cells, identified as neuroepithelial bodies (NEBs) stained positively for either CGRP or PGP 9.5 in the bronchioles, and these were observed during all stages examined. CGRP or PGP 9.5 positive nerve fibers appeared during the perinatal periods and increased in number after birth. However, neither serotonin nor chromogranin A immunoreactivity was observed in NEBs or nerve fibers in the airway at any of the examined developmental stages.

Key words: CGRP, PGP 9.5, Serotonin, Chromogranin A, Development of rat respiratory tract

\section{Introduction}

Among the neurotransmitters, the ontogeny of calcitonin gene-related peptide (CGRP) immunoreactivity has been studied most extensively in the respiratory system of various animals including the rat $[3,10,15,22,25]$. This peptide is distributed in the endocrine cells of the respiratory mucosa as well as in nerve fibers and related to the functions include hypoxia-sensitive chemoreceptors or sensory afferent system in the lung $[3,12,15,19,25,29]$. Similarly, the development of serotonin immunoreactivity has been examined with respect to the APUD cells in the respiratory mucosa. However, the expression of serotonin in APUD cells in the respiratory mucosa has been studied in rabbits [4, 5, 13, 14] and hamsters [22] rather than the rat. The studies demonstrated that these bioactive peptides or amines are widely distributed throughout the neuroendocrine cells, neuroepithelial bodies (NEBs) and/or nerves, and thus the coexistence of

Correspondence to: Dr. Mineko Fujimiya, Department of Anatomy, Shiga University of Medical Science, Seta, Otsu, Shiga 520-21, Japan. such pan-neuroendocrine marker proteins as protein gene product (PGP) 9.5 or chromogranins has been investigated. PGP 9.5 is a cytoplasmic neuron-specific protein that is used as a general marker of systemic neurons $[6,17,28]$. Previous studies have shown that PGP 9.5 is distributed in the respiratory system $[1,17,26]$. However, these studies were restricted to investigating the adult animal model. Little has been reported regarding the development of this protein. Chromogranin $\mathrm{A}$ is an acidic secretory protein and a potential marker for the neuroendocrine tissues and neoplasms [10, 18, 23, 30]. Localization of chromogranin A immunoreactivity in the respiratory system has been performed in several mammals $[11,16]$. However, very few studies have investigated the development of this immunoreactivity in the airway.

The present study investigated changes in overall distribution of CGRP, PGP 9.5, serotonin and chromogranin $\mathrm{A}$ in the rat developing respiratory tract with an emphasis on the endocrine and neuronal characteristics of the immunoreactive structures. 


\section{Materials and Methods}

Wistar rat fetuses from embryonic days (ED) 15, 17, 19, 20, 21 and neonatal rats from postnatal days (PD) 0,1 , $3,7,11,14,20,21,30,60$ were investigated. Four animals were obtained from each developmental stage and the day of conception was defined as embryonic day 0 . The pregnant rats were anesthetized with pentobarbital (Nembutal ${ }^{\circledR}$, Abbot, USA, $50 \mathrm{mg} / \mathrm{kg}$ ) and the fetuses were removed from the uterus. Fetuses were anesthetized with ice and the neonates were anesthetized with an intraperitoneal injection of pentobarbital $(25 \mathrm{mg} / \mathrm{kg})$. The respiratory tract and lungs were fixed by either immersion for $2 \mathrm{hr}$ (ED 15) or transcardiac perfusion (ED 17 to PD 60) with a fixative containing $4 \%$ paraformaldehyde, $0.5 \%$ glutaraldehyde and $0.2 \%$ picric acid in $0.1 \mathrm{M}$ phosphate buffer (PB, pH 7.4) at $4^{\circ} \mathrm{C}$. The specimens were then immersed for $24 \mathrm{hr}$ in a post-fixative containing $4 \%$ paraformaldehyde and $0.2 \%$ picric acid in $0.1 \mathrm{M} \mathrm{PB}(\mathrm{pH} \mathrm{7.4)}$ at $4^{\circ} \mathrm{C}$. After washing for 4 days with $0.1 \mathrm{M} \mathrm{PB}$ containing $15 \%$ sucrose which was routinely changed, the specimens were immersed overnight in $0.1 \mathrm{M}$ PB containing $10 \%$ gelatin at $37^{\circ} \mathrm{C}$. The gelatin-embedded specimens were cooled to $4^{\circ} \mathrm{C}$, fixed for $3 \mathrm{hr}$ with $4 \%$ paraformaldehyde in $0.1 \mathrm{M} \mathrm{PB}$, and then immersed for more than $3 \mathrm{hr}$ in $0.1 \mathrm{M}$ $\mathrm{PB}$ containing $15 \%$ sucrose at $4{ }^{\circ} \mathrm{C}$. The gelatin-embedded specimens were cut into $16 \mu \mathrm{m}$ thick sections using a cryostat (Reichert-Jung, Germany) and the sections were collected in $0.1 \mathrm{M}$ PBS $(0.1 \mathrm{M}$ PB containing $0.9 \% \mathrm{NaCl}$, $\mathrm{pH} 7.4$ ) containing $0.3 \%$ Triton $\mathrm{X}-100$ (PBST) at $4{ }^{\circ} \mathrm{C}$.

The sections were treated in the free-floating state throughout the immunohistochemical procedures. Each sample was incubated with either the CGRP antibody (polyclonal, Peninsula Lab. CA, USA, diluted $1: 5,000$ in PBST), PGP 9.5 antibody (polyclonal, UltraClone Ltd. England, diluted $1: 5,000$ in PBST), 5HT antibody (polyclonal [7], diluted $1: 5,000$ in PBST) or chromogranin A antibody (polyclonal, Yanaihara Institute, Japan, diluted 1:5,000 in PBST) for $72 \mathrm{hr}$ at $4{ }^{\circ} \mathrm{C}$. In order to inactivate endogenous peroxidase activity, the sections were incubated at room temperature (RT) for $20 \mathrm{~min}$ with $0.1 \% \mathrm{H}_{2} \mathrm{O}_{2}$ in $0.1 \mathrm{M} \mathrm{PBS}$, followed by an additional $20 \mathrm{~min}$ with $0.1 \%$ phenylhydrazine in PBS. After washing for $30 \mathrm{~min}$ with PBST, the sections were incubated at RT for $2 \mathrm{hr}$ in biotinylated anti-rabbit IgG (Vector Lab. Inc., USA) diluted $1: 1,000$ in PBST. The sections were then washed for $30 \mathrm{~min}$ and placed at RT for $1.5 \mathrm{hr}$ in avidin-biotin-peroxidase complex (Elite, Vector) diluted $1: 1,000$ in PBST. Immunoreactivity was then determined by reacting the samples with $0.05 \mathrm{M}$ Tris- $\mathrm{HCl}$ buffer (pH 7.6) containing 0.01\% 3, 3'-diaminobenzidine, $1 \%$ ammonium nickel sulfate and $0.0003 \% \mathrm{H}_{2} \mathrm{O}_{2}$ for $30 \mathrm{~min}$ at RT. The stained sections were mounted on gelatin-coated glass slides, dehydrated by graded ethanol, and coverslipped with Entellan ${ }^{\circledR}$ (Merck, Darmstadt, Germany).

The specificity of the positive staining was examined by a preabsorption study performed on the sections from ED 15. The primary antibody against CGRP, PGP 9.5, serotonin or chromogranin A was substituted with the antibody (diluted $1: 5,000$ ) preabsorbed with either $100 \mu \mathrm{M}$ CGRP, PGP 9.5, serotonin or chromogranin A. The antigen and antibody mixture was incubated for $48 \mathrm{hr}$ at $4{ }^{\circ} \mathrm{C}$ before incubating the sections. Positive reactivity to CGRP, PGP 9.5, serotonin or chromogranin A was completely eliminated in sections subjected to the preabsorption study. The antibody specificity against serotonin was described precisely in our previous paper [7].

\section{Results}

\section{CGRP immunoreactivity}

On ED 15, the entire circumference of the epithelium of the primitive bronchi was stained by CGRP and the basal and apical sites of the epithelial cells were darkly stained by the DAB reaction (Fig. 1A). On ED 17, CGRP-positive epithelial cells extended toward the distal bronchi, whereas the epithelial cells in the proximal bronchi were no longer stained (Fig. 1B). On ED 19, dense CGRP-positive cells were observed more distally in the fine bronchioles. In addition, a relatively small number of positive cells were found in the medium-sized or proximal bronchioles (Fig. 1C). On ED 20, the density of CGRPpositive cells in the periphery decreased slightly compared to ED 19. Neuroepithelial bodies (NEBs) consisting of clusters of CGRP-positive cells first appeared in the proximal region of the bronchioles (Fig. 1D). On ED 21, CGRP-positive cells were no longer evidenced in the peripheral airways but the number of CGRP-positive NEBs in the bronchioles increased (Table 1, Fig. 1E). These CGRP-positive NEBs were seen in the bronchioles throughout the perinatal and postnatal periods (Table 1, Fig. 1-F, G, I). CGRP-positive nerve fibers first appeared beneath the epithelium of the proximal bronchioles on PD 3 and gradually increased in number with age (Table 2, Fig. 1-H, I, J).

\section{PGP 9.5 immunoreactivity}

On ED 15, the epithelium of the primitive bronchi was stained diffusely with PGP 9.5 (Fig. 2A). On ED 17, PGP 9.5 positive cells were widely distributed toward the distal region of the bronchioles. The density of positive cells in the periphery increased on ED 17 and ED 19 (Table 1, Fig. 2B). However, the density decreased dramatically on ED 21 (Table 1, Fig. 2C). On the day of birth (PD 0), NEBs were positively stained with PGP 9.5 and found primarily in the proximal region of the bronchioles (Fig. 2D). This finding was found throughout the postnatal period (Table 1, Fig. 2-E, F, H). In contrast, PGP 9.5 immunoreactive nerve fibers that lined the lobar bronchus first appeared on ED 21 (Fig. 2C) and increased in number after birth (Table 2, Fig. 2-E, G). These fibers were frequently located in close proximity to PGP 9.5 immunoreactive NEBs (Fig. 2-D, F, H). 


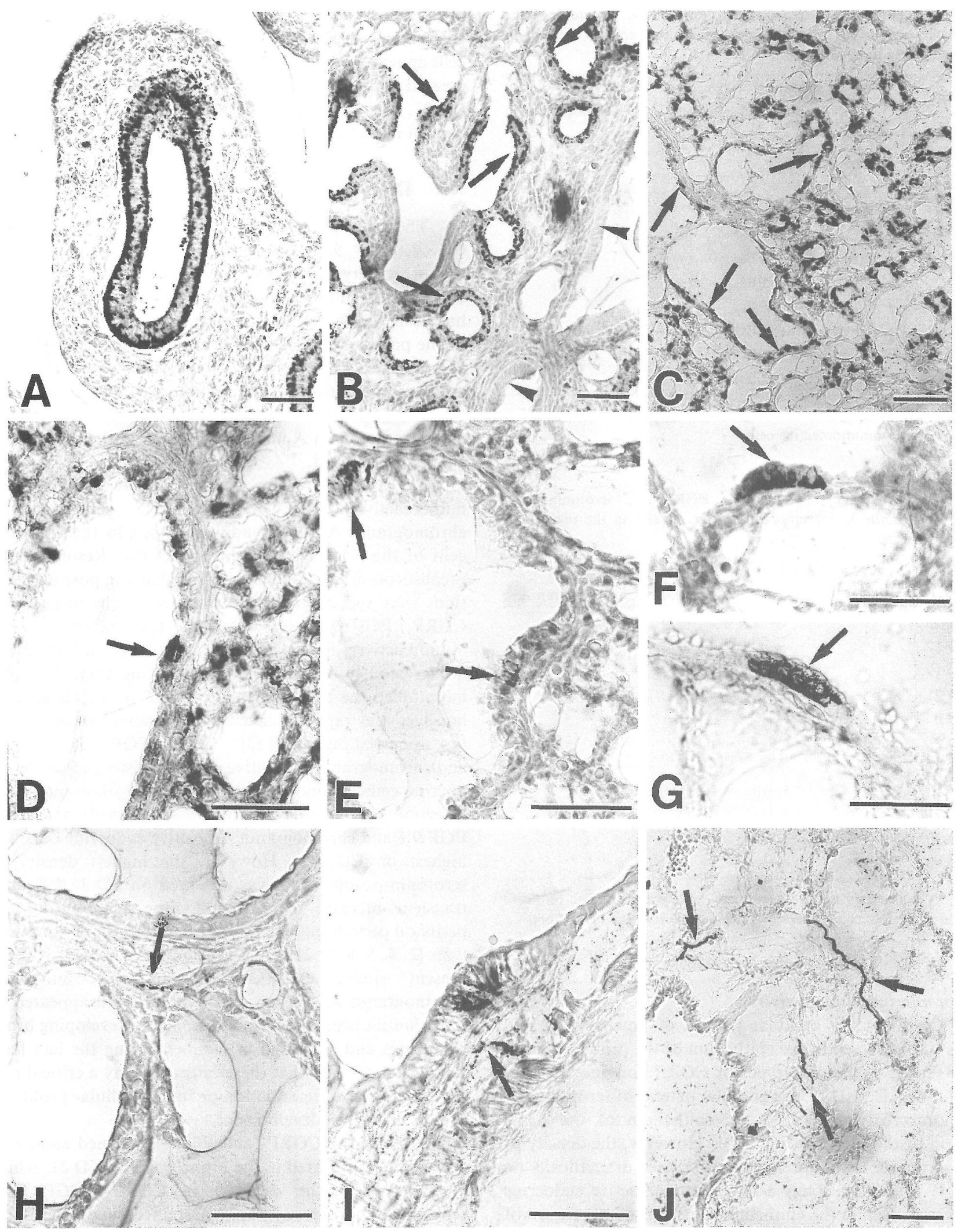

Fig. 1. CGRP immunoreactivity in the airway of fetal and postnatal rats. Bars $=50 \mu \mathrm{m}$. A: ED 15. Epithelial cells of primitive bronchi are darkly stained. B: ED 17. Epithelial cells of distal bronchi are stained (arrows), but those of proximal bronchi are not stained (arrow heads). C: ED 19. CGRP-positive cells locate further distally in the fine bronchioles. Relatively small number of positive cells are seen in the medium-sized or proximal bronchioles (arrows). D: ED 20. CGRP-positive cells in the peripheral portion decreased the number and the cluster of positive cells (NEBs) appear in proximal bronchiole (arrow). E: ED 21. Positive cells are not seen in peripheral region, but CGRPpositive NEBs increase in number (arrows). F: PD 0 and G: PD 2, CGRP-positive NEBs in the bronchioles (arrows). H: PD 3. CGRPpositive nerve fibers appear beneath the epithelium of proximal bronchiole (arrow). I: PD 11. CGRP-positive NEBs and nerve fibers (arrow) are seen. J: PD 60. CGRP-positive nerve fibers (arrows) are seen. 
Table 1. Frequency of CGRP-, PGP 9.5-, serotonin- and chromogranin A- immunoreactive endocrine cells in developing respiratory tract of rat.

\begin{tabular}{lcccc}
\hline \multirow{2}{*}{ Days } & \multicolumn{4}{c}{ Immunoreactive endocrine cells } \\
\cline { 2 - 5 } & CGRP & PGP 9.5 & Serotonin & Chromogranin A \\
\hline ED 15 & ++ & ++ & ++ & ++ \\
ED 17 & +++ & +++ & +++ & +++ \\
ED 19 & +++ & +++ & + & +++ \\
ED 21 & ++ (NEBs) & + & - & - \\
PD 0 & + (NEBs) & + (NEBs) & - & - \\
PD 3 & + (NEBs) & + (NEBs) & - & - \\
PD 7 & + (NEBs) & + (NEBs) & - & - \\
PD 14 & + (NEBs) & + (NEBs) & - & - \\
PD 21 & + (NEBs) & + (NEBs) & - & - \\
PD 30 & + (NEBs) & + (NEBs) & - & - \\
PD 60 & + (NEBs) & + (NEBs) & - & - \\
\hline
\end{tabular}

+++ , Numerous cells; ++ , moderate number of cells; + , a few cells; - , no immunoreactive cells

Table 2. Frequency of CGRP-, PGP 9.5-, serotonin- and chromogranin A- immunoreactive nerve fibers in the respiratory tract of rat.

\begin{tabular}{lcccc}
\hline \multirow{2}{*}{ Days } & \multicolumn{5}{c}{ Immunoreactive nerve fibers } \\
\cline { 2 - 5 } & CGRP & PGP 9.5 & Serotonin & Chromogranin A \\
\hline ED 15 & - & - & - & - \\
ED 17 & - & - & - & - \\
ED 19 & - & - & - & - \\
ED 21 & - & + & - & - \\
PD 0 & - & + & - & - \\
PD 3 & + & + & - & - \\
PD 7 & ++ & ++ & - & - \\
PD 14 & ++ & +++ & - & - \\
PD 21 & ++ & +++ & - & - \\
PD 30 & ++ & +++ & - & - \\
PD 60 & +++ & +++ & - & - \\
\hline
\end{tabular}

+++ , Numerous nerve fibers; ++ , moderate number of nerve fibers; + , a few nerve fibers; - , no immunoreactive nerve fibers

\section{Serotonin immunoreactivity}

On ED 15, a granular pattern of positively stained cells was observed in the epithelium of the primitive bronchi, similar to that observed for CGRP immunoreactivity (Fig. 3A). On ED 17, the granular pattern of serotonin immunoreactivity spread to the epithelium of the distal region of the bronchi (Fig. 3B). However, the density of the serotonin immunoreactivity decreased dramatically on ED 19 (Fig. 3C). Only a few immunoreactive endocrine cells were seen in the epithelium of the proximal region of the bronchioles (Fig. 3D). No immunoreactive structures were observed in the airway after ED 21 (Table 1).

\section{Chromogranin A immunoreactivity}

On ED 15, the inner portion of the epithelium of the primitive bronchi stained positive for chromogranin A (Fig. 4A). On ED 17, chromogranin A positive epithelial cells appeared in the distal region of the bronchioles and increased in number on ED 19 (Fig. 4B and Table 1). After ED 21, chromogranin A positive cells were no longer evident in any of the sections (Table 1).

\section{Discussion}

The present study investigated the development of CGRP, PGP 9.5, serotonin and chromogranin A immunoreactivity in the perinatal respiratory tract. The development of immunoreactivity of CGRP and serotonin has been widely investigated previously. However, most of the previous studies have investigated rabbits $[4,5,13$, 14], hamsters [22] or pigs [13]; only one study investigated the development of CGRP immunoreactivity in rat tissue [3]. As a result, the development of serotonin, PGP 9.5 and chromogranin A immunoreactivity in the rat was not clearly understood.

The present results clearly indicate that the immunoreactivity of CGRP, PGP 9.5, serotonin and chromogranin A has already developed in the epithelial cells of the primitive bronchi by ED 15 . Results of the preabsorption study demonstrated that the positive reactions were specific to these substances. The presence of CGRP, PGP 9.5, serotonin or chromogranin A immunoreactivity in the rat respiratory tract on ED 15 has not previously been demonstrated. One previous paper has studied the development of CGRP in the rat airway, however they reported that CGRP-positive endocrine cell first appeared on ED 17 [3]. CGRP, PGP 9.5, serotonin and chromogranin A positive cells, consisting of single endocrine cells, extended distally and were observed in the developing bronchioles on ED 17. The density of CGRP, PGP 9.5 and chromogranin A positive endocrine cells was highest on ED 19. However, the highest density of serotonin-positive cells was observed on ED 17. Such a transient increase in neuroendocrine cells during the perinatal periods has been widely reported for various peptides $[2,4,5,8,9,21,24,27]$ including CGRP [3]. In the present study, CGRP, PGP 9.5, serotonin and chromogranin A positive endocrine cells all appeared at the primitive bronchi, extended along the developing bronchial trees and increased in number during the late fetal periods, suggesting that these cells may play a critical role for the cellular differentiation or for the cellular proliferation in bronchial development.

A cluster of CGRP- and PGP 9.5-stained endocrine cells (NEBs) appeared in the bronchioles on ED 21, which coincided with the decrease in CGRP-, PGP 9.5-, serotonin- and chromogranin A-stained single endocrine cells in the distal airway. CGRP and PGP 9.5 positive NEBs were found throughout all the later developmental stages examined in the present study. Expression of PGP 9.5 in the NEBs has been demonstrated previously in adult mammals including the rat $[1,17,26]$. However, the 


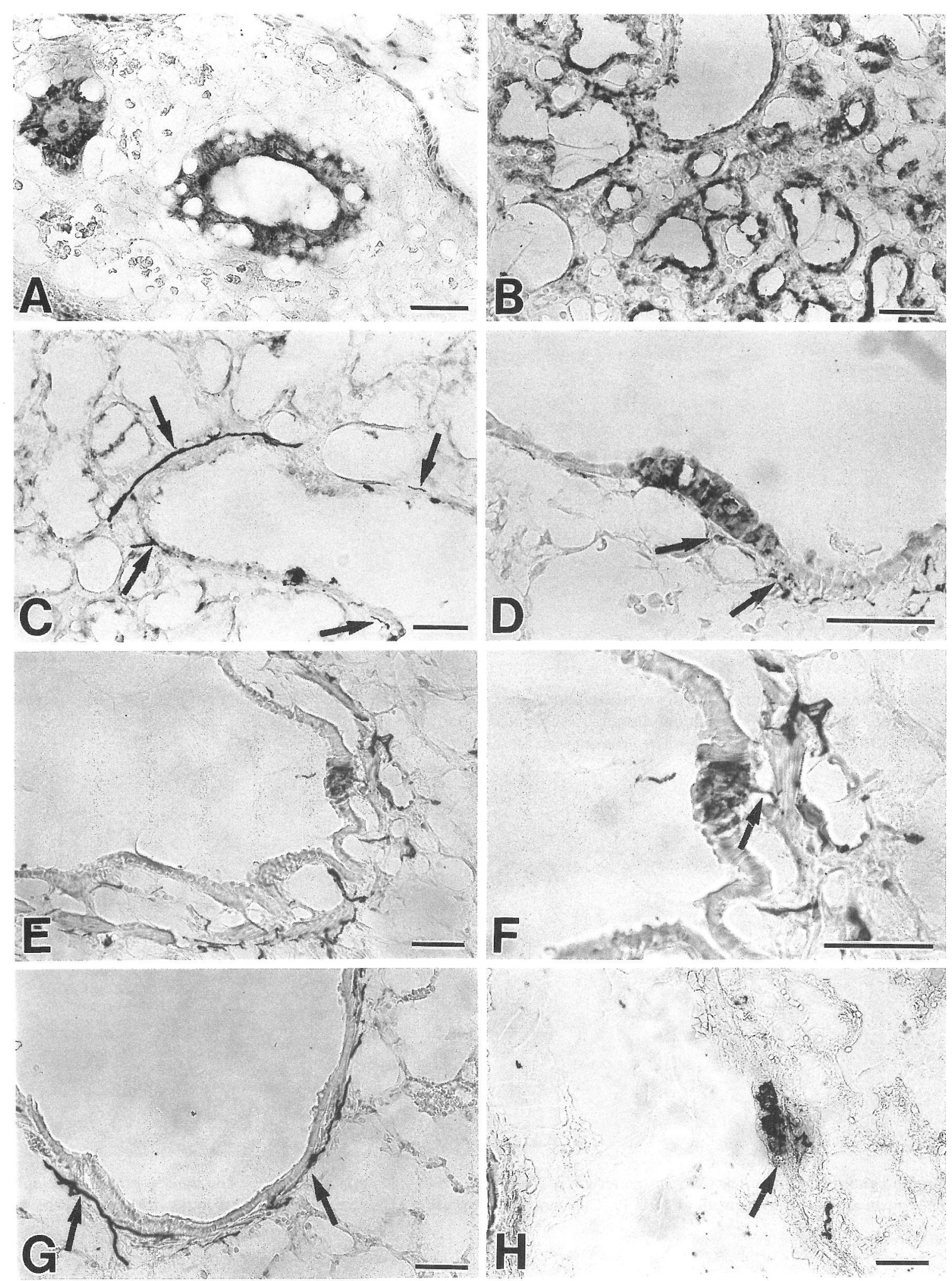

Fig. 2. PGP 9.5 immunoreactivity in the airway of fetal and postnatal rats. Bars $=50 \mu \mathrm{m}$. A: ED 15 . Epithelial cells of primitive bronchi are stained. B: ED 19. Positive cells are densely distributed in the distal part of bronchioles. C: ED 21. The density of positive cells in the peripheral region decrease and PGP 9.5 positive nerve fibers appear lining the lobar bronchus (arrows). D: PD 0. PGP 9.5 positive NEBs and nerve fibers are seen. Fibers locate close to the NEBs (arrows). E: PD 14. Positive NEBs and nerve fibers. F: Higher magnification of E. Nerve fibers locate close to the NEBs (arrow). G: PD 20. PGP 9.5 positive nerve fibers line the bronchus (arrows). H: PD 60. Positive NEBs (arrow) and nerve fibers. 

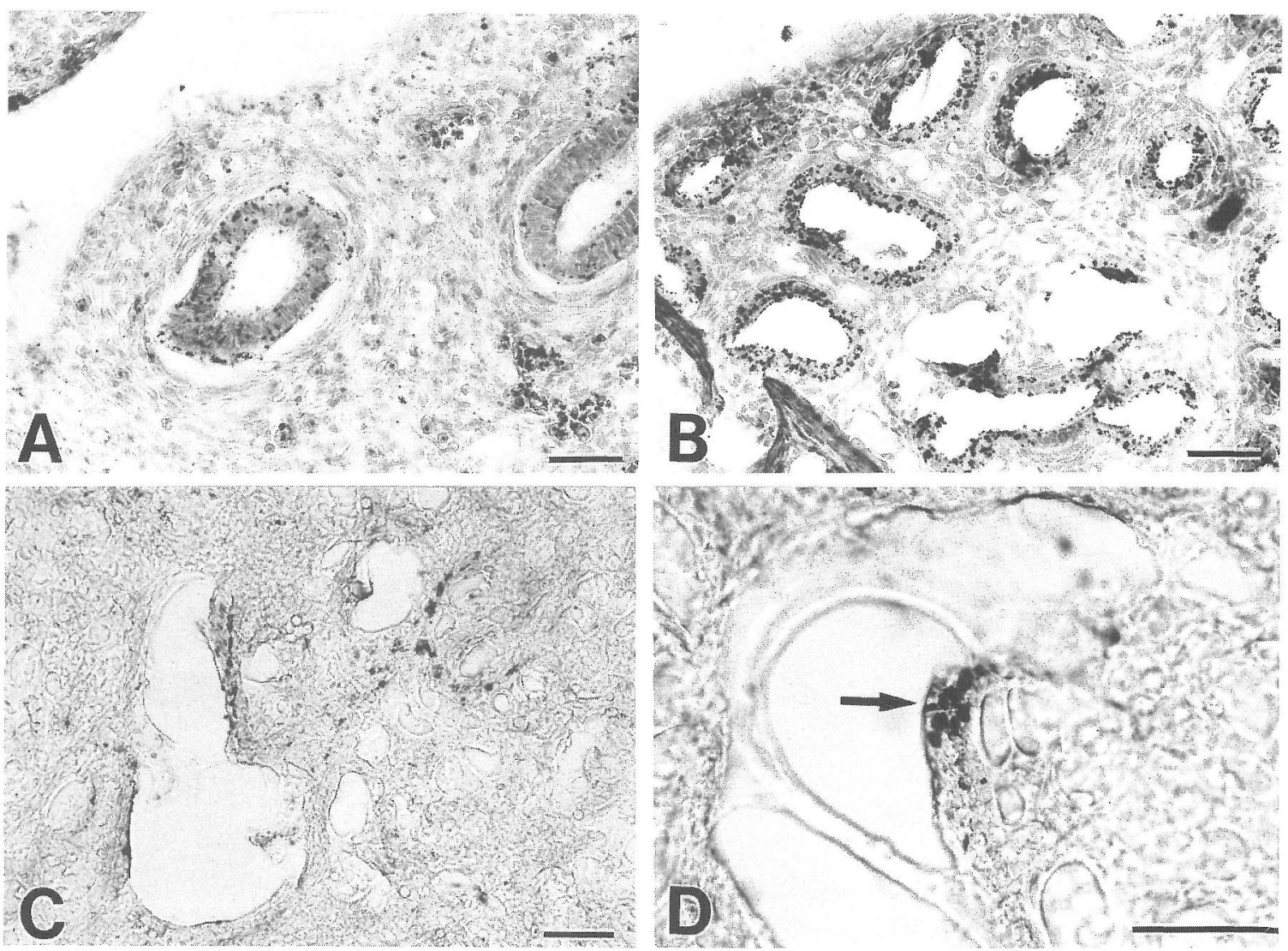

Fig. 3. Serotonin immunoreactivity in the airway of fetal rats. Bars $=50 \mu \mathrm{m}$. A: ED 15 . The epithelium of primitive bronchi are stained in a granular pattern. B: ED 17. Epithelium of distal part of bronchi is positively stained. C: ED 19. The density of positive cells decreased dramatically. D: ED 19. Only a few positive cells are seen on the bronchiole (arrow).
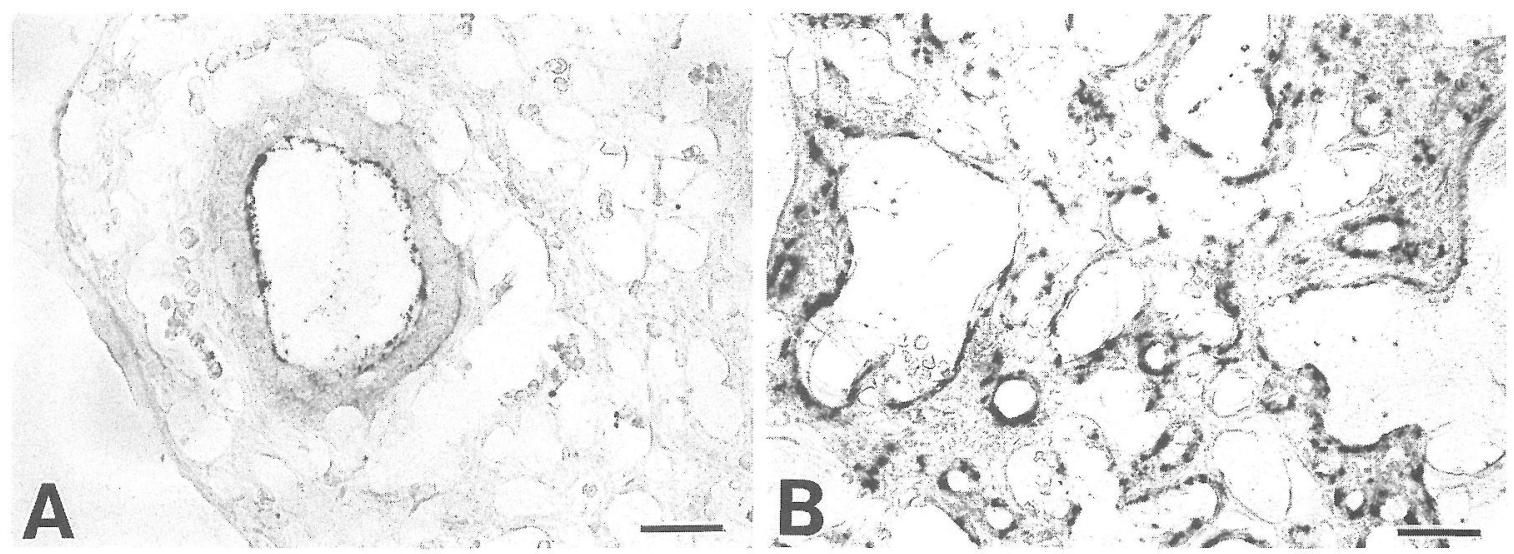

Fig. 4. Chromogranin A immunoreactivity in the airway of fetal rats. Bars $=50 \mu \mathrm{m}$. A: ED 15. The inner portion of the epithelium of primitive bronchi are positively stained. B: ED 19. Chromogranin A positive cells increase the number in the distal part of the bronchioles.

development of PGP 9.5 in the airway has not been examined previously. Since CGRP-positive NEBs increased following hypoxic treatment [26], NEBs in the respiratory tract are thought to be hypoxia-sensitive chemoreceptors [4]. The present results, which showed parallel development of CGRP- and PGP 9.5-positive NEBs, suggest that these structures may play a role as chemoreceptors at the perinatal and postnatal periods. No serotonin- nor chromogranin A-positive NEBs were found during any of the stages examined. Previously the coexistence of serotonin and CGRP in the NEBs has been shown in adult or developing airway of hamster [22], rabbit [4] cat and pig 
[13]. Discrepancy between present and previous studies may be due to difference in species. In fact, in adult rat airway, a few serotonin [20] and no chromogranin A [16] immunoreactive structures have been reported previously.

CGRP and PGP 9.5 immunoreactive nerve fibers appeared lining the bronchial trees or blood vessels at perinatal periods and gradually increased their number after birth. Previous studies have shown that PGP 9.5 is present in nerve fibers in the adult rat airway but the developmental process has not been reported [17]. In the present study, the frequency of PGP 9.5-positive nerve fibers was always higher than that of CGRP-positive fibers, suggesting that PGP 9.5 fibers may contain peptides other than CGRP.

Both PGP 9.5 and chromogranin A are pan-neuroendocrine markers and are known to be distributed in APUD cells $[1,28]$. PGP 9.5 is a cytoplasmic neuron-specific protein $[6,17,28]$, therefore it is used as a potential marker for neurons. While chromogranin A is a secretory granule related protein $[1,18,30]$, therefore it is used as a potential marker for endocrine cells. The present study demonstrated that PGP 9.5 and chromogranin A positive cells were distributed differently in the developing rat airway. PGP 9.5 was widely distributed in single endocrine cells, NEBs and nerve fibers. However chromogranin A was distributed only in single endocrine cells but not in NEBs. Similarly, NEBs were negative for serotonin. These results suggest that in the rat respiratory tract, NEBs possess neural rather than endocrine characteristics.

\section{References}

1. Adriaensen, D. and Scheuermann, D. W.: Neuroendocrine cells and nerves of the lung. Anat. Rec. 236; 70-85, 1993.

2. Balaguer, L. and Romano, J.: Solitary neuroendocrine cells and neuroepithelial bodies in the lower airways of embryonic, fetal, and postnatal sheep. Anat. Rec. 231; 333-338, 1991.

3. Cadieux, A., Springall, D. R., Mulderry, P. K., Rodrigo, J., Ghatei, M. A., Terenghi, G., Bloom, S. R. and Polak, J. M.: Occurrence, distribution and ontogeny of CGRP immunoreactivity in the rat lower respiratory tract: effect of capsaicin treatment and surgical denervations. Neuroscience 19; 605-627, 1986.

4. Cho, T., Chan, W. and Cutz, E.: Distribution and frequency of neuroepithelial bodies in postnatal rabbit lung. Quantitative study with monoclonal antibody against serotonin. Cell Tissue Res. 255; 353-362, 1989.

5. de Bock, V., Yoshizaki, K. and Solomon, S.: Serotonin content of rabbit lung and small intestine during perinatal development. Life Sci. 38; 431-435, 1986.

6. Doran, J. F., Jackson, P., Kynoch, P. A. M. and Thompson, R. J.: Isolation of PGP 9.5, a new human neurone-specific protein detected by high-resolution two-dimensional electrophoresis. J. Neurochem. 40; 1542-1547, 1983.

7. Fujimiya, M., Kimura, H. and Maeda, T.: Postnatal development of serotonin nerve fibers in the somatosensory cortex of mice studied by immunohistochemistry. J. Comp. Neurol. 246; 191-201, 1986.

8. Ghatei, M. A., Sheppard, M. N., Henzen-Logman, S., Blank, M. A., Polak, J. M. and Bloom, S. R.: Bombesin and vasoactive intestinal polypeptide in the developing lung: marked changes in acute respiratory distress syndrome. J. Clin. Endocrinol. Metab. 57; 1226-1232, 1983.

9. Gosney, J. R.: Neuroendocrine cell populations in postnatal human lungs: minimal variation from childhood to old age. Anat. Rec. 236; 177-180, 1993.

10. Johnson, D. E. and Wobken, J. D.: Calcitonin gene-related peptide immunoreactivity in airway epithelial cells of the human fetus and infant. Cell Tissue Res. 250; 579-583, 1987.

11. Kalina, M. and Grimelius, L.: Chromogranins or chromogranin-like proteins are present in lamellar bodies and pulmonary surfactant of rat alveolar type II cells. $J$. Histochem. Cytochem. 39; 213-220, 1991.

12. Keith, I. M., Pelto-Huikko, M., Schalling, M. and Hökfelt, T.: Calcitonin gene-related peptide and its mRNA in pulmonary neuroendocrine cells and ganglia. Histochemistry 96; 311-315, 1991.

13. Lauweryns, J.M., de Bock, V., Verhofstad, A. A. J. and Steinbusch, H.W.M.: Immunohistochemical localization of serotonin in intrapulmonary neuroepithelial bodies. Cell Tissue Res. 226; 215-223, 1982.

14. Lauweryns, J. M., Van Ranst, L. and Verhofstad, A. A. J.: Ultrastructural localization of serotonin in the intrapulmonary neuroepithelial bodies of neonatal rabbits by use of immunoelectron microscopy. Cell Tissue Res. 243; 455-459, 1986.

15. Lauweryns, J. M. and Van Ranst, L.: Calcitonin gene-related peptide immunoreactivity in rat lung: light and electron microscopic study. Thorax 42; 183-189, 1987.

16. Lauweryns, J. M., Van Ranst, L., Lloyd, R. V. and O'Connor, D. T.: Chromogranin in bronchopulmonary neuroendocrine cells. Immunocytochemical detection in human, monkey, and pig respiratory mucosa. J. Histochem. Cytochem. 35; 113-118, 1987.

17. Lauweryns, J. M. and Van Ranst, L.: Protein gene product 9.5 expression in the lungs of humans and other mammals. Immunocytochemical detection in neuroepithelial bodies, neuroendocrine cells and nerves. Neurosci Lett. 85; 311-316, 1988.

18. Lloyd, R. V., Iacangelo, A., Eiden, L. E., Cano, M., Jin, L. and Grimes, M.: Chromogranin A and B messenger ribonucleic acids in pituitary and other normal and neoplastic human endocrine tissues. Lab. Invest. 60; 548-556, 1989.

19. Lundberg, J. M., Franco-Cereceda, A., Hua, X., Hökfelt, T. and Fischer, J. A.: Co-existence of substance $\mathrm{P}$ and calcitonin gene-related peptide-like immunoreactivities in sensory nerves in relation to cardiovascular and bronchoconstrictor effects of capsaicin. Eur. J. Pharmacol. 108; 315-319, 1985.

20. Luts, A., Uddman, R., Absood, A., Håkanson, R. and Sundler, F.: Chemical coding of endocrine cells of the airways: presence of helodermin-like peptides. Cell Tissue Res. 265; 425-433, 1991.

21. Matsui, S., Fujimiya, M., Matsui, J., Amakata, Y., Renda, T., Kimura, H. and Maeda, T.: Localization of [D-Ala $\left.{ }^{2}\right]$ deltorphin I-like immunoreactivity in perinatal rat respiratory system. Histochem. J. 26; 648-654, 1994.

22. McDowell, E. M., Hoyt, R. F. Jr. and Sorokin, S. P.: Ontogeny of endocrine cells in the respiratory system of Syrian golden hamsters. II. Intrapulmonary airways and alveoli. Cell Tissue Res. 275; 157-167, 1994.

23. Said, J. W., Vimadalal, S., Nash, G., Shintaku, I. P., Heusser, R. C., Sassoon, A. F. and Lloyd, R. V.: Immunoreactive neuron-specific enolase, bombesin, and chromogranin as markers for neuroendocrine lung tumors. Hum. Pathol. 16; 236-240, 1985.

24. Salvi, E. and Renda, T.: An immunohistochemical study on neurons and paraneurons of the pre- and post-natal chicken lung. Arch. Histol. Cytol. 55; 125-135, 1992.

25. Scheuermann, D. W., Timmermans, J. -P., Adriaensen, D. and 
De Groodt-Lasseel, M. H. A.: Immunoreactivity for calcitonin gene-related peptide in neuroepithelial bodies of the newborn cat. Cell Tissue Res. 249; 337-340, 1987.

26. Springall, D. R., Collina, G., Barer, G., Suggett, A. J., Bee, D. and Polak, J. M.: Increased intracellular levels of calcitonin gene-related peptide-like immunoreactivity in pulmonary endocrine cells of hypoxic rats. J. Pathol. 155; 259-267, 1988.

27. Stahlman, M. T., Kasselberg, A. G., Orth, D. N. and Gray, M. E.: Ontogeny of neuroendocrine cells in human fetal lung. II. An immunohistochemical study. Lab. Invest. 52; 52-60, 1985.
28. Thompson, R. J., Doran, J. F., Jackson, P., Dhillon, A. P. and Rode, J.: PGP 9.5 - a new marker for vertebrate neurons and neuroendocrine cells. Brain Res. 278; 224-228, 1983.

29. Uddman, R., Luts, A. and Sundler, F.: Occurrence and distribution of calcitonin gene-related peptide in the mammalian respiratory tract and middle ear. Cell Tissue Res. 241; 551-555, 1985.

30. Varndell, I. M., Lloyd, R. V., Wilson, B. S. and Polak, J. M.: Ultrastructural localization of chromogranin: a potential marker for the electron microscopical recognition of endocrine cell secretory granules. Histochem. J. 17; 981-992, 1985. 